\title{
KUALITAS INFORMASI TERHADAP CITRA DESTINASIPASAR TERAPUNG PADA WISATAWAN DOMESTIK
}

\author{
Najla Amaly
}

UIN Antasari Banjarmasin

\begin{abstract}
This study aimed to identify the effect on the image quality destination information Travel Floating Market on domestic tourists who are domiciled in the city of Banjarmasin. In the year 2014-2015 has been designated as the year for the promotion of South Kalimantan province in the restructuring program of Library Air Travel Banjarmasin by the local government. This program has continued to the present, so that the local government is still heavily in the promotion tours. The local government has made tourism promotion through marketing communications mix. Particularly Travel Floating Market is an icon of South Kalimantan which became the main attraction which was appointed by the local government to promote the city of Banjarmasin as the City of a Thousand Rivers. But over the years there has been no attempt to evaluate the results of the promotion. Whether the information provided has been perceived positively by tourists or not. BPS data from Banjarmasin has occurred rise and fall of the number of tourist visiting the city of Banjarmasin. In 2014 the decline in the number of tourists visiting the city of Banjarmasin. Banjarmasin city government that has never evaluates whether the information of the marketing communications mix Banjarmasin Floating Market has succeeded in creating a positive image for tourists. This study uses the theory of $S-O-R$ where stimulus effect on the response. This research is a quantitative explanation. By distributing questionnaires to 100 respondents of research, the results of this study based on the analysis done by simple linear regression analysis, it can be concluded that the quality of information significant effect on the image of the destination. Values influence of independent variables in this study has a value of $27.4 \%$ in affecting the image of the destination.
\end{abstract}

Keywords: quality of information, citra destinations, travel floating market, Banjarmasin 


\section{Pendahuluan}

Penelitian ini tentang pengaruh antara kualitas informasi terhadap citra destinasi Pasar Terapung Kota Banjarmasin pada wisatawan domestik yang berdomisili di Kota Banjarmasin. Tema ini menarik untuk diteliti karena pada tahun 2014-2015 ditetapkan sebagai tahun promosi bagi Provinsi Kalimantan Selatan dalam program pembenahan Wisata Pustaka Air Kota Banjarmasin oleh pemerintah setempat. Program ini terus dilakukan sampai sekarang, sehingga pemerintah setempat masih gencar dalam melakukan promosi wisata. Pemerintah setempat telah melakukan promosi wisata melalui bauran komunikasi pemasaran. Khususnya Wisata Pasar Terapung yang merupakan ikon Wisata Kalimantan Selatan yang menjadi daya tarik utama yang diangkat oleh pemerintah setempat untuk mempromosikan Kota Banjarmasin sebagai Kota Seribu Sungai. Namun dari tahun ke tahun belum ada upaya untuk mengevaluasi hasil dari promosi tersebut. Apakah informasi destinasi melalui bauran komunikasi pemasaran pemerintah setempat telah tersampaikan dengan baik dan dimaknai positif oleh wisatawan. Dari data BPS Kota Banjarmasin telah terjadi penurunan jumlah wisata yang berkunjung ke Kota Banjarmasin pada tahun 2014. Asumsi dari penelitian ini adalah adanya pengaruh kualitas informasi terhadap citra destinasi Pasar Terapung. Sehingga penelitian dapat menjelaskan pengaruh kualitas informasi terhadap citra destinasi Pasar Terapung.

Citra destinasi menjadi faktor penting saat ini dalam menghadapi persaingan wisata yang semakin ketat. Menurut Arturo Molina et al (2010:2) "through tourism imagery and representation, plays a vital role in a highly competitive and constantly changing marketplace”. Melalui citra dan representasi pariwisata, memainkan perang penting dalam pasar yang sangat kompetitif dan terus berubah. Dari pendapat Molina diatas menjelaskan bahwa citra positif pada objek wisata memiliki peran penting, dimana dapat mempengaruhi keputusan konsumen yang nantinya akan menjadi potensi berkunjung ke objek wisata tersebut, sebaliknya jika objek wisata memiliki citra yang negatif maka keputusan konsumen juga akan negatif yaitu tidak tertarik untuk berkunjung.

Pengertian citra destinasimenurut Lawson dan Bond-Bovy (1977) dalam jurnal Zhang (2014) "An expression of knowledge, impressions, prejudice, imaginations and emotional thoughts an individual has of a specific object or place”. Ekspresi dari pengetahuan, tayangan, prasangka, imajinasi dan pikiran emosional seorang individu 
terhadap suatu objek atau tempat tertentu. Sehingga citra destinasimerupakan persepsi seseorang yang dipengaruhi oleh stimulus-stimulus yang diterima pada suatu objek tempat.

Citra destinasi dapat dibentuk melalui pengalaman individu dan informasi yang didapat. Menurut Reynolds (1965) dalam echtner and ritchie (1993:3) pembentukan citra telah dijelaskan oleh sebagai pengembangan konstruksi pikiran yang didasarkan pada beberapa tayangan yang dipilih dari curahan informasi. Informasi yang dimaksud seperti literature promosi (brosur travel, opinion dari keluarga, kerabat dan travel agent dan media massa). Menurut Tasci dan Kozak (2006) dalam jurnal RA Putri dkk (2015) bahwa citra destinasiadalah persepsi individu terhadap karakteristik destinasi yang dapat dipengaruhi oleh informasi promosi, media massa serta banyak faktor lainnya. Sehingga informasi tentang objek wisata menjadi faktor penting dalam mempengaruhi citra, khususnya citra destinasiyang dibentuk sebelum seseorang melakukan pengalaman berkunjung ke wisata. Dimana citra dibentuk dari informasi-informasi yang didapat dari berbagai media. Pendapat ini didukung oleh model citra destinasimenurut Beerli dan Martin (2004) dalam jurnal Khodadadi (2012) bahwa terdapat dua faktor yang membentuk citra destinasisalah satunya faktor information sources. Sehingga sangat penting dalam memberikan informasi yang menarik bagi wisatawan yang belum pernah berkunjung. Dengan kualitas informasi yang baik akan membentuk image yang baik pula dan dapat menarik wisatawan untuk datang.

Pendapat diatas didukung oleh pendapat Suwardjono (2001:58) dalam jurnal Dyva Yulisda dan MC Ninik S.R (2014), kualitas informasi adalah karakteristik yang melekat pada informasi sehingga informasi bermakna bagi pemakai dan memberi keyakinan kepada pemakai sehingga bermanfaat dalam keputusan. Kualitas informasi dapat mempengaruhi keputusan komunikan. Makna dari informasi yang berkualitas tersampaikan kepada komunikan, sesuai makna informasi yang dimaksud oleh komunikator.

Penelitian ini meneliti kualitasdari informasi Wisata Pasar Terapung. Berdasarkan pendapat Burgess (1978) dalam jurnal khairani (2009:20) salah satunya menghipotesakan bahwa kualitas dari informasi mempengaruhi citra yang akan dibangun. Pengaruh informasi terhadap pembentukan citra destinasi juga terdapat pada model tujuh tahapan dari pengalaman perjalanan oleh Gunn (1988) dalam echtner and 
ritchie (1993:3). Pada tahapan awal sebelum terjadinya tahap keputusan untuk melakukan perjalanan liburan, terdapan tahapan yaitu akumulasi citra dalam pikiran tentang pengalaman perjalanan dan modifikasi citra tersebut dengan informasi lebih lanjut.

Menurut Darmawan (2001:2) bahwa informasi yang dapat memberikan makna bagi pengguna diantaranya, Amount of Information, quality of Information,recency of Information, relevance of Information, accuracy of Information, autehnticity of Information. Dari pendapat Darmawan (2012) diatas dapat disimpulkan bahwa kualitas informasi memiliki peran penting dalam menyampaikan pesan yang akan dimaknai oleh penerima informasi. Dan informasi yang telah dimaknai tersebut akan membentuk sebuah persepsi di dalam benak penerima informasi tersebut.

Menurut Kepala Bappeda Kota Banjarmasin Nurul Fajar Desira, Pemerintah Kota Banjarmasin sedang menjalankan program pembenahan tempat Wisata Pustaka Air mulai dari tahun 2013. Pada tahun 2014 sampai tahun 2015 menjadi tahun promosi yang bertujuan untuk mencapai tujuan yaitu meningkatkan wisatawan yang datang ke Kota Banjarmasin. Dan pada tahun 2015, pemerintah menetapkan tahun 2015 menjadi tahun kunjungan wisata. (http://kabarbanjarmasin.com/posting/banjarmasin-kotapusaka-tepi-air.html, diakses pada 2 Oktober 2015 pukul 11.55). Hal tersebut merupakan salah satu alasan peneliti, meneliti citra destinasi Kota Banjarmasin. Selain hal tersebut, berdasarkan hasil penelitian peneliti sebelumnya ditemukan bahwa belum adanya tindakan evaluasi pemerintah setempat terhadap kegiatan promosi yang dilakukan. Sehingga belum diketahui apakah informasi yang disampaikan oleh pemerintah setempat telah dimaknai positif oleh wisatawan dan apakah informasi yang disampaikan memiliki kualitas baik.

Pasar Terapung adalah salah satu wisata perairan sungai yang paling terkenal dari Kalimantan Selatan dan menjadi ikon wisata Kota Banjarmasin. Walaupun saat ini wisata Pasar Terapung terdapat pula di daerah lain seperti Bogor, Lembang maupun Sumatera, wisata Pasar Terapung Kota Banjarmasin merupakan wisata apung pertama yang ada di Indonesia dan merupakan wisata budaya. Pasar Terapung Kota Banjarmasin juga merupakan satu-satunya wisata Pasar Apung di Indonesia yang masuk dalam list destinasi pesona Indonesia. Hal ini yang menjadi alasan peneliti dalam meneliti citra destinasiWisata Pasar Terapung. 
Pasar Terapung di Kalimantan Selatan terdiri dari dua tempat yaitu Lok Baintan yang bertempat di Kabupaten Banjar dan Muara Kuin bertempat di Kota Banjarmasin. Para pedagang Pasar Terapung melakukan transaksi jual beli dengan menggunakan perahu atau dalam bahasa Banjar disebut dengan jukung.Perahu-perahu pedagang ini membawa beraneka ragam sayur-mayur, buah-buahan, ikan, kue dan lain-lain. Sistem perdagangannya masih ada yang menggunakan sistem perdagangan tradisional yaitu barter. Keunikan Pasar Terapung ini membawa Pasar Terapung menjadi objek wisata yang terkenal di Indonesia dan menjadi tujuan wisata nasional.

Pasar Terapung menjadi objek wisata yang tidak lepas dari daya tarik untuk keberhasilan program pembenahan Wisata Pustaka Air. Pasar terapung yang merupakan ikon wisata dari Provinsi Kalimantan Selatan yang terkenal dengan sebutan Kota Seribu Sungai, menjadi daya tarik utama pada program promosi wisata Kalimantan Selatan. Pasar terapung yang sudah hampir 400 tahun usianya ini dikabarkan semakin sepi dan terancam punah, khususnya Pasar Terapung Muara Kuin di Kota Banjarmasin. Pasar Terapung Muara Kuin yang berada di Kota Banjarmasin ini tidak memiliki organisasi pasar seperti pasar di darat, dan tidak ada sistem tiket masuk wisata sehingga tidak ada data jumlah pedagang dan pengunjung. Namun berdasarkan data Pemerintah Kota Banjarmasin dalam Yulianus(2014) bahwa pada tahun 2014 pedagang Pasar Terapung sekitar 160 pedagang dimana pada tahun 1980 jumlah pedagang lebih dari 300 pedagang(Kompas, 8 Februari 2014). Sehingga pemerintah setempat melakukan program untuk melestarikan dan mempromosikan wisata Pasar Terapung.

Menurut data Badan Pusat Statistik Kota Banjarmasin, data jumlah wisatawan yang datang ke Kota Banjarmasin dihitung dari data tamu yang menginap di penginapan Kota Banjarmasin menunjukkan bahwa adanya penurunan jumlah pengunjung pada tahun 2014 dan 2015 jika dibandingkan dengan tahun 2013. Pada tahun 2013 wisatawan domestik mencapai 357.351 tamu. Namun pada tahun 2014, wisatawan domestik mencapai 304.508 jumlah tamu domestic, dan pada tahun 2015, wisatawan domestik mencapai 317.002. Dari data wisatawan yang datang ke Kota Banjarmasin, pada tahun promosi Kota Banjarmasin malah mengalami penurunan jumlah wisatawan dibandingkan jumlah wisatawan sebelum tahun promosi pada tahun 2013. Hal ini tidak sesuai dengan tujuan pemerintah setempat yang telah melakukan promosi yang gencar 
melalui berbagai bauran komunikasi pemasaran untuk mensukseskan tahun kunjungan wisata pada tahun 2015 .

Berbagai komunikasi pemasaran dilakukan oleh Dinas Pariwisata Kota Banjarmasin menggunakan saluran komunikasi. Berdasarkan hasil penelitian sebelumnya oleh Najla Amaly (2014) bauran komunikasi pemasaran wisata Pasar Terapung diantaranya menggunakan iklan televisi lokal dan baliho, kemudian humas dan publisitas dalam bentuk event tahunan, bulletin, brosur, dan VCD profil wisata yang disebarkan untuk tamu-tamu daerah, perhotelan dan masyarakat umum. Selanjutnya menggunakan publikasi tentang Wisata Pasar Terapung di media massa dan media online, seperti Banjarmasin Post, Kompas, MNC TV Kalsel. Personel selling yaitu kunjungan Dinas Pariwisata Banjarmasin ke Dinas Pariwisata daerah lain dan sosialisasi duta wisata Nanang Galuh Banjar ke sekolah-sekolah di Kota Banjarmasin. Pemasaran langsung berupa website resmi Dinas Pariwisata Kota Banjarmasin dan website Banjarmasin heritage yang didalamnya mencakup informasi objek wisata, event wisata, jadwal Banjarmasin Heritage tour, berita terkait dan peta wisata Kota Banjarmasin.

Dari penelitian terdahulu ini diketahui bahwa belum adanya evaluasi yang dilakukan oleh pemerintah setempat untuk mengevalusi keberhasilan komunikasi pemasaran yang telah dilakukan. Ditemukannya kelemahan-kelemahan dari saluran komunikasi yang telah digunakan oleh pemerintah setempat untuk mempromosikan Pasar Terapung. Seperti halnya saluran komunikasi berupa media kompilasi wisata Kota Banjarmasin (bulletin, brosur, dan VCD) didistribusikan ke hotel-hotel di Kota Banjarmasin, namun ketika dikonfirmasi kelima hotel berbintang di Kota Banjarmasin, 4 dari 5 hotel (Hotel Rattan inn, Hotel Swiss Bel, Hotel Palm, Hotel Batung Batulis) menyatakan bahwa tidak adanya pemberian media kompilasi tersebut dari Dinas Pariwisata Kota Banjarmasin. Sedangkan 1 hotel yaitu Hotel Banjarmasin Internasional mengatakan bahwa media tersebut diberikan jika ada acara dinas di hotel tersebut. Padahal media kompilasi ini dicetak 500 buah setiap tahunnya.

Sama halnya dengan website Dinas Pariwisata Kota Banjarmasin http://www.banjarmasinkota.go.id/page/6/ dan Website Banjarmasin heritagewww.Banjarmasinheritage.com. Website ini mencakup informasi tentang objek wisata, event wisata, info travel dan hotel, maupun berita terkait dan peta wisata Kota Banjarmasin. Namun kedua website resmi Dinas Pariwisata ini sering mengalami 
gangguan dalam mengaksesnya, bahkan website Banjarmasin heritage tidak lagi ditemukan. Padahal anggaran untuk website resmi tersebut menurut data anggaran dari Disbudparpora Kota Banjarmasin anggaran untuk website pada tahun 2014 mencapai Rp 30.400.000/tahun dan setiap tahunnya anggaran tersebut bertambah Rp 2.400.000,setiap tahunnya.

Penyampaian informasi juga dilakukan melalui publikasi di media massa dalam menyampaikan informasi tentang Wisata Pasar Terapung. Menurut Rungkuti (2009:27) publikasi merupakan permintaan pembuatan berita atau hasil wawancara yang bersifat komersial tentang produk tersebut yang disebarkan melalui media. Publikasi Pasar Terapung telah banyak dipublikasikan di media massa lokal, nasional maupun internasional. Publikasi Pasar Terapung tidak selalu merupakan berita baik atau positif namun juga ada berita negative. Salah satu contohnya seperti liputan Indonesia Metro Tv tentang aktivitas Pasar Terapung Lok Baintan pada bulan Mei 2015, dan liputan Net10 di Net TV tentang Pasar Terapung memprihatinkan pada bulan Oktober 2015. Informasi-informasi yang didapat dari saluran komunikasi inilah yang nantinya akan membentuk citra.

Responden penelitian ini merupakan wisatawan domestik yang berdomisili di Kota Banjarmasin. Dari table 1.1 dibawah dijelaskan bahwa bauran komunikasi pemasaran Dinas Pariwisata Kota Banjarmasin memiliki segmentasi kepada wisatawan domestik. Agar bisa mengukur semua kualitas informasi bauran komunikasi pemasaran maka penelitian ini mengambil responden wisatawan domestik. Sedangkan seluruh bauran komunikasi pemasaran Dinas Pariwisata Kota Banjarmasin dipublikasikan di Kota Banjarmasin. Dan tidak semua bauran komunikasi pemasaran Dinas Pariwisata Kota Banjarmasin dipublikasikan di luar Kota Banjarmasin. Bauran komunikasi yang digunakan untuk menjangkau wisatawan diluar Kota Banjarmasin hanya sebatas melalui publikasi media televisi, website, dan kunjungan Duta Wisata Kota Banjarmasin ke Dinas Pariwisata kota lain. 
Tabel 1.1 Segmentasi bauran komunikasi pemasaran

\begin{tabular}{|l|l|l|}
\hline $\begin{array}{l}\text { Buran Komunikasi } \\
\text { Pemasaran }\end{array}$ & $\begin{array}{l}\text { Segmentasi sang } \\
\text { Direncanakan }\end{array}$ & $\begin{array}{l}\text { Segmentasi setelah } \\
\text { Dilaksanakan }\end{array}$ \\
\hline Iklan & Nasional dan lokal & Nasional dan lokal \\
\hline Humas dan publitas & Nasional dan lokal & Nasional dan lokal \\
\hline Personel selling & Nasional dan lokal & Nasional dan lokal \\
\hline Pemasaran langsung & Asing & Nasional dan lokal \\
\hline
\end{tabular}

Sumber: Amaly. (2014). Skripsi Bauran Komunikasi Pemasaran Wisata Pasar Terapung dalam Meningkatkan Wisatawan Kota Banjarmasin

Berdasarkan penjelasan diatas, peneliti akan meneliti fenomena ini dengan model S-O-R (Stimulus, Organism, Respons). Dalam penelitian ini stimulus yaitu informasi wisata Pasar Terapung melalui bauran komunikasi pemasaran Dinas Pariwisata Kota Banjarmasin. Organism dalam penelitian ini adalah wisatawan domestik yang berdomisili di Kota Banjarmasin. Hal ini dikarenakan seluruh bauran komunikasi pemasaran Dinas Pariwisata Kota Banjarmasin dapat dijangkau keseluruhan di Wilayah Kota Banjarmasin. Sedangkan tidak semua bauran komunikasi pemasaran dapat dijangkau di luar Kota Banjarmasin. Respons dalam penelitian ini adalah citra destinasiwisatawan pada Wisata Pasar Terapung.

Hasil penelitian terdahulu yang berjudul "Pengaruh Kualitas Informasi Website Terhadap Citra Pemerintah Kabupaten Wonogiri" bahwa kualitas informasi berpengaruh pada citra perusahaan. Informasi yang didapat dari website Pemerintah Kabupaten Wonogiri dapat mempengaruhi citra pemerintah dengan nilai yang cukup baik. Persamaan penelitian terdahulu dengan penelitian yang akan dilakukan yaitu meneliti pengaruh kualitas informasi terhadap citra. Perbedaan dengan penelitian terdahulu adalah penelitian ini tidak hanya meneliti kualitas informasi pada satu media website saja, namun beberapa sumber informasi, yaitu dari bauran komunikasi pemasaran yang dimiliki Dinas Pariwisata Kota Banjarmasin yang terdiri dari iklan, media kompilasi, website, dan lain-lain.

Penelitian terdahulu yang kedua berjudul "Promoting Tourism Destination Image" oleh Robert Govers et al. Jurnal ini meneliti peran promosi pariwisata sebagai komponen pembentukan citra destinasi.Persamaan penelitian ini dengan penelitian yang 
dilakukan peneliti adalah penelitian ini sama-sama meneliti informasi dari bauran komunikasi pemasaran wisata yang mempengaruhi citra destinasi. Perbedaan penelitian terdahulu dengan penelitian yang akan dilakukan adalah penelitian terdahulu terfokus pada mengetahui sumber informasi yang wisatawan gunakan. Sedangkan penelitian ini ingin mengetahui sumber informasi yang digunakan wisatawan dan juga meneliti kualitas dari informasi bauran komunikasi pemasaran tersebut.

Dari penjabaran diatas disimpulkan bahwa penelitian dapat menjelaskan pengaruh kualitas informasi terhadap citra destinasiPasar Terapung, melalui bauran komunikasi pemasaran Dinas Pariwisata Kota Banjarmasin.

\section{Pembahasan}

Penelitian ini bertujuan untuk mengetahui apakah adanya pengaruh kualitas informasi terhadap citra destinasi Wisata Pasar Terapung Kota Banjarmasin. Variabel dalam penelitian ini (kualitas informasi dan citra destinasi)telah terbukti berdistribusi normal dan tidak terjadi heteroskedastisitas. Sehingga penelitian ini dapat menggunakan analisis data regresi linier sederhana.

Menurut Burgess (1978) dalam Lisa Zhang (2014:14) bahwa kualitas sumber informasi mempengaruhi citra destinasi. Pendapat Burgess (1978) ini mendukung hasil analisis penelitian ini, dari hasil survey kepada 100 responden penelitian yang merupakan wisatawan domestik yang berdomisili di Kota Banjarmasin yang belum pernah berkunjung ke Wisata Pasar Terapung dengan menggunakan instrumen penelitian yaitu kuesioner, ditemukan bahwa adanya pengaruh antara kualitas informasi terhadap citra destinasi.

Tabel 5.15 Nilai Signifikasnsi

\begin{tabular}{|l|l|}
\hline Variabel Bebas & Sig \\
\hline (Constant) & 0.000 \\
Kualitas Informasi & 0.000 \\
\hline
\end{tabular}

Berdasarkan tabel 5.17 diatas dapat diperoleh penjelasan bahwa tingkat signifikansi variabelkualitas informasisig $<\alpha(0,05)$, sehingga hasil yang didapat yaitu 
ditolak H0. Sehingga menunjukkan bahwa kualitas informasi berpengaruh signifikan terhadap citra destinasi.

Tabel 5.16 Hasil Uji Adjusted R Square

\begin{tabular}{|l|l|}
\hline Model & Adjusted R Square \\
\hline 1 & 0.274 \\
\hline
\end{tabular}

Berdasarkan tabel 5.17 menunjukkan bahwa variabel bebas pada penelitian ini yaitu kualitas informasi hanya berpengaruh sebesar $27,4 \%$ terhadap citra destinasi.

Dari hasil data yang diperoleh dari responden, seluruh responden mendapatkan informasi mengenai Wisata Pasar Terapung berawal melalui WOM (word of mouth) yang didapat dari keluarga maupun kerabat yang pernah berkunjung ke Pasar Terapung.Namun informasi yang didapat hanya sebatas memperkenalkan atau memberitahukan bahwa terdapat wisata Pasar Terapung di Kota Banjarmasin. Informasi yang didapat tidak lengkap dan rujukan tidak formal dan tidak berasal dari pihak profesional, sehingga responden juga telah mencari informasi Wisata Pasar Terapung melalui sumber rujukan yang formal yaitu melalui bauran komunikasi pemasaran Dinas Pariwisata Kota Banjarmasin. Mrinmoy (2007:2) juga menjelaskan bahwa WOM (word of mouth) merupakan rujukan yang tidak formal atau tidak resmi, sedangkan publikasi pariwisata resmi seperti brosur wisata, publikasi media massa memiliki sumber yang professional.

Penelitian ini memfokuskan penelitian untuk mengetahui kualitas informasi formal yaitu bauran komunikasi pemasaran Dinas Pariwisata Kota Banjarmasin. Bauran komunikasi pemasaran Dinas Pariwisata Banjarmasin terdiri dari delapan jenis bauran komunikasi pemasaran yaitu iklan televisi, baliho atau spanduk, media Kompilasi (bulletin, brosur, dan VCD), publikasi/Liputan di televisi, pemberitaan di Koran, pemberitaan di media online, sosialisasi oleh Duta Wisata Nanang Galuh Kota Banjarmasin, website resmi Dinas Pariwisata Kota Banjarmasin. Berdasarkan hasil kuesioner bauran komunikasi pemasaran yang digunakan wisatawan paling banyak yaitu publikasi TV dan paling sedikit yaitu website Dinas Pariwisata.

Bauran komunikasi pemasaran Dinas Pariwisata Kota Banjarmasin berupa iklan televisi telah dipilih 22 responden dari 100 responden yang ada sebagai sumber informasi utama dalam mendapatkan informasi tentang Wisata Pasar Terapung. Iklan 
televisi merupakan sumber informasi kedua paling banyak dipilih oleh responden penelitian setelah publikasi Televisi. Bauran komunikasi pemasaran iklan televisi Wisata Pasar Terapung diiklankan melalui saluran televisi lokal yaitu MNC KALSEL. Berdasarkan pengamatan peneliti, iklan ini ditayangkan ketika menjelang dan ketika berlangsungnya acara Festival Pasar Terapung yang dilaksanakan satu kali dalam satu tahun. Bauran komunikasi pemasaran ini merupakan bentuk kerjasama MNC TV dengan Dinas Pariwisata Kota Banjarmasin dalam mempromosikan destinasi Pasar Terapung. Informasi yang disampaikan pada iklan televisi ini yaitu penjelasan tentang apa yang ada didalam Wisata Pasar Terapung dimana informasi tersebut disampaikan dengan menarik melalui pantun dan lagu Banjar. Pada iklan televisi tersebut digambarkan pedagang Pasar Terapung yang mengayuh perahunya ke lokasi Pasar Terapung.

Bauran komunikasi pemasaran Dinas Pariwisata Kota Banjarmasin berupa baliho dan spanduk telah dipilih 2 responden dari 100 responden yang ada sebagai sumber informasi utama dalam mendapatkan informasi tentang Wisata Pasar Terapung. Baliho dan spanduk hanya terdapat di Siring Tandean yang merupakan lokasi Wisata Pasar Terapung Siring Tandean. Wisata Pasar Terapung Siring Tandean merupakan objek wisata baru di pusat Kota Banjarmasin. Kemudian baliho dan spanduk juga dipasang di depan Kantor Pemerintah Kota Banjarmasin, Airport Syamsudin Noor dan Siring Sungai Martapura. Baliho dan spanduk dipasang hanya ketika saat menjelang event tahunan festival Pasar Terapung. Informasi dari baliho dan spanduk hanya menyampaikan lokasi Pasar Terapung.

Bauran komunikasi pemasaran Dinas Pariwisata Kota Banjarmasin berupa Media kompilasi telah dipilih 2 responden dari 100 responden yang ada sebagai sumber informasi utama dalam mendapatkan informasi tentang Wisata Pasar Terapung. Menurut Dinas Pariwisata Kota Banjarmasin Media kompilasi disebarkan di pusat informasi, hotel-hotel dan dibagikan di masyarakat. Namun ketika peneliti melakukan pengecekan di hotel-hotel berbintang di Kota Banjarmasin. Tidak ada yang mendapatkan media kompilasi dari pemerintah setempat. Salah satu hotel ternama di Kota Banjarmasin mengungkapkan bahwa media kompilasi hanya ada ketika berlangsungnya acara pemerintah setempat di hotel tersebut. Informasi destinasi yang ada di media kompilasi menyangkup informasi yang paling lengkap dibandingkan 
bauran komunikasi pemasaran lainnya. Bauran komunikasi pemasaran media kompilasi terdiri dari buletin, VCD dan Brosur wisata Kota Banjarmasin.

Buletin destinasi Kota Banjarmasin terdapat dua jenis yaitu buletin Pesona Destinasi Wisata Pesona Destinasi Wisata dan Kompilasi Wisata Seni dan Budaya Kota Banjarmasin. Buku Kompilasi Wisata Seni dan Budaya ini menyangkup informasi mengenai seni dan budaya Kota Banjarmasin. Kemudian terdapat Buletin Kompilasi Wisata Seni dan Budaya, buletin ini tidak hanya mempromosikan wisata Pasar Terapung namun juga objek wisata lainnya. Buletin ini merupakan buku panduan seluruh objek wisata, seni dan budaya Kota Banjarmasin. Informasi bulletinini selain menginformasikan wisata Kota Banjarmasin juga menjelaskan tentang sarana prasarana wisata, jadwal tour Kota Banjarmasin dan Martapura, Sekilas Kota Banjarmasin, event Wisata Kota Banjarmasin. Dikarenakan faktor pendistribusian bauran ini yang tidak baik sehingga banyak wisatawan yang tidak mendapatkan informasi dari media kompilasi wisata Kota Banjarmasin.

Bauran komunikasi pemasaran Dinas Pariwisata Kota Banjarmasin berupa publikasi televisi telah dipilih 41 responden dari 100 responden yang ada sebagai sumber informasi utama dalam mendapatkan informasi tentang Wisata Pasar Terapung. Publikasi televisi merupakan sumber informasi paling banyak dipilih oleh responden. Publikasi wisata Pasar Terapung melalui media televisi banyak ditemukan setiap tahunnya. Dalam mempromosikan Pasar Terapung secara nasional maupun Internasional Dinas Pariwisata Kota Banjarmasin mengandalkan publisitas dari media massa dari acara kuliner, kunjungan artis ibukota, berita dari surat kabar, televisi dan internet. Seperti pada tahun 2013 Presiden Indonesia Susilo Bambang Yudhoyono mendatangi wisata Pasar Terapung, moment ini membuat banyak media massa memberitakannya. Hal ini membantu mempromosikan Pasar Terapung secara Nasional bahkan Internasional. Bauran komunikasi pemasaran publikasi televise ini dianggap responden lebih lengkap dan mudah untuk dipahami informasinya. Publikasi televisi wisata Pasar Terapung ditayangkan pada siaran televisi lokal maupun nasional.

Selain publikasi televisi juga terdapat publikasi melalui berita koran, dari 100 responden ada 9 responden yang memilih berita koran sebagai sumber informasi utama dalam mendapatkan informasi tentang Wisata Pasar Terapung. Publikasi dari media online juga banyak ditemukan berupa artikel-artikel berita online. Dan dari 100 
responden ada 19 responden yang memilih Berita media online sebagai sumber informasi utama dalam mendapatkan informasi tentang Wisata Pasar Terapung. Responden yang memilih berita media online sebagai sumber informasi utamanya mayoritas merupakan anak remaja sekolah atau mahasiswa.

Bauran komunikasi pemasaran Dinas Pariwisata Kota Banjarmasin berupa sosialisasi duta wisata telah dipilih 4 responden dari 100 responden yang ada sebagai sumber informasi utama dalam mendapatkan informasi tentang Wisata Pasar Terapung. Sosialisasi duta wisata dilakukan oleh Nanang Galuh Banjarmasin, dimana duta wisata Kota Banjarmasin ini memberikan sosialisasi tentang objek wisata di Kota Banjarmasin kepada pelajar dan mahasiswa Banjarmasin. Namun responden anak sekolah tidak ada yang mendapatkan sosialisasi dari duta wisata.

Bauran komunikasi pemasaran Dinas Pariwisata Kota Banjarmasin berupa website Dinas Pariwisata telah dipilih 1 responden dari 100 responden yang ada sebagai sumber informasi utama dalam mendapatkan informasi tentang Wisata Pasar Terapung. Website Dinas Pariwisata sering mengalami error ketika di akses, bahkan website Banjarmasin Herritage yang di miliki oleh Dinas Pariwisata Kota Banjarmasin sebagai website khusus destinasi tidak lagi ditemukan. Padahal informasi di website Banjarmasinherritage.com ini sangat lengkap.

Menurut Sutabri (2004) dalam Widyatama (2012) kualitas informasimerupakan informasi yang dihasilkan oleh sistem informasi yang memiliki tiga karakteristik yaitu accuracy dimana informasi harus bebas dari kesalahan-kesalahan dan tidak bias atau menyesatkan, timeliness dimana informasi yang datang pada penerima tidak boleh terlambat, informasi yang usang tidak akan mempunyai nilai lagi, sehingga informasi harus selalu up to date dan relevance dimanainformasi harus relevan terhadap kebutuhan pengguna atau mempunyai manfaat untuk penggunanya.

Berdasarkan temuan hasil analisis penelitian menunjukkan bahwa Koefisien regresi pada variabel kualitas informasi adalah sebesar 0,565berarti jika kualitas informasi naik sebesar satu satuan maka citra destiansi akan naik sebesar 0,565. Sehingga kualitas informasiberpengaruh positif terhadap citra destinasi. Hal ini membuktikan bahwa bauran komunikasi pemasaran Dinas Pariwisata Kota Banjarmasin sudah memiliki kualitas yang baik dalam membentuk citra positif Wisata Pasar Terapung Kota Banjarmasin. 
Berdasarkan teori, menurut Walter Lipman dalam Benedecta dan Ninik (2014:16) memaparkan bahwa,

"proses pembentukan citra terhadap suatu obyek, organisasi atau individu tertentu, terdapat empat komponen penting yaitu persepsi, kognisi, motivasi dan sikap. Persepsi yang merupakan hasil pengamatan terhadap unsur lingkungan yang dikaitkan dengan suatu proses pemaknaan. Individu akan memberikan makna terhadap rangsangan berdasarkan pengalamannya mengenai rangsangan. Persepsi atau pandangan individu akan positif apabila informasi yang diberikan oleh rangsangan dapat memenuhi kognisi individu. Kognisi yaitu suatu keyakinan diri dari individu terhadap stimulus. Keyakinan akan timbul apabila individu telah mengerti rangsangan tersebut, sehingga individu harus diberikan informasi-informasi yang cukup yang dapat mempengaruhi perkembangan kognisinya. Selanjutnya, motif adalah keadaan dalam pribadi seseorang yang mendorong keinginannya melakukan kegiatankegiatan tertentu guna mencapai suatu tujuan. Sedangkan sikap, adalah kecendrungan bertindak, berpersepsi, berpikir guna menghadapi obyek, ide, situasi atau nilai. Sikap bukan perilaku, tetapi merupakan kecendrungan untuk berperilaku dengan cara tertentu."

Pendapat ini menunjukkan bahwa ketika informasi yang disampaikan dipersepsikan dengan baik oleh komunikator, mampu menambah pengetahuan serta menimbulkan motivasi dan akhirnya dapat membentuk sikap yang positif. Sehingga dapat disimpulkan bahwa semakin baik kualitas informasinya maka semakin baik citra pada objek tersebut.

\section{Simpulan}

Berdasarkan hasil analisis yang dilakukan dengan menggunakan analisis regresi linier sederhana, maka dapat ditarik kesimpulan bahwa kualitas informasi berpengaruh signifikan terhadap citra destinasi. Dan nilai pengaruh dari variabel bebas pada penelitian ini yang merupakan variabel kualitas informasimemiliki nilai 27,4\% dalam mempengaruhi citra destinasi. Dan 72,6\% lainnya merupakan faktor lain diluar variabel bebas dari penelitian ini yang mempengaruhi citra destinasi.

Kualitas informasiyang memiliki tiga indikator yaitu accuracy, timeliness dan relevance terbukti bernilai baik. Accuracy merujuk kepada kepercayaan dan kepahaman wisatawan terhadap informasi Pasar Terapung melalui bauran komunikasi pemasaran. Accuracy informasi Wisata Pasar Terapung bauran komunikasi pemasaran dinilai baik. 
Timeliness merujuk kepada tepat waktunya dan up to date informasi Pasar Terapung. Timeliness informasi Wisata Pasar Terapung bauran komunikasi pemasaran dinilai baik. Dan relevan merujuk kepada Informasi Pasar Terapung melalui bauran komunikasi pemasaran tersebut sesuai kebutuhan dan mengurangi ketidakpastian atau keraguan. Relevan informasi dinilai baik.

Citra destinasi Wisata Pasar Terapung Kota Banjarmasin yang dinilai dari tiga indikator yaitu jumlah keyakinan (belief), harapan (ideals) dan kesan (impressions) dinilai baik. Dari hasil analisis juga diketahui bahwa dari delapan bauran komunikasi pemasaran Dinas Pariwisata Kota Banjarmasin responden paling banyak mendapatkan informasi Wisata Pasar Terapung melalui publikasi televisi dan paling sedikit melalui website Dinas Pariwisata Kota Banjarmasin.

\section{Daftar Pustaka}

\section{Buku:}

Ardianto, Elvinaro dkk. 2009. Komunikasi Massa; Suatu Pengantar. Bandung: Simbiosa.

Avraham, Eli and E.Ketter. 2008. Media Strategies for Marketing Place in Crisis: Improying the Image of Cities, Countries, and Tourist Destinations. Oxford: Butterworth-Heinemann.

Bungin, Burhan. 2013. Metodologi Penelitian Sosial dan Ekonomi, Jakarta: Kencana.

Idrus, Muhammad. 2007. Metode Penelitian Ilmu Sosial Pendekatan Kualitatif dan Kuantitatif Edisi Kedua. Jakarta: Erlangga.

Janianton Damanik, Phil. 2013. Pariwisata Indonesia: antara peluang dan tantangan. Yogyakarta: Pustaka Pelajar.

Karyono, A. Hari. 1997. Kepariwisataan. Jakarta: Grasindo.

Kennedy, John. ER dan Dermawan Soemanagara. 2006. Marketing Communication -. Taktik dan Strategi.Jakarta: PT Buana Ilmu Populer.

Kotler, Philip dan Kevin Lane Keller. 2009. Manajemen Pemasaran I (Edisi 13). Jakarta: Erlangga.

Lemeshow, S., dkk. 1997, Besar Sampel dalam Penelitian Kesehatan. Gadjah Mada University Press: Yogyakarta. 
Manfeld, Yoel and Abraham Pizam. 2001. Tourism, Security \& Safety from Theory to Practice First Edition. New York: Routledge.

Mc Cabe, Scoot.2009. Marketing Communications in Tourism and Hospitality Concepts, Strategis and Cass. Oxford UK: Elsevier.

Mulyana, Deddy. 2007. Ilmu Komunikasi Suatu Pengantar. Bandung: Rosda.

M.A, Morrison. 2010. Periklanan Komunikasi Pemasaran Terpadu. Jakarta: Kencana.

M. Morrison, Alastair. 2002. Hospitaly and Travel Marketing Third Marketing Third Edition, US: Delmar Thomson Learning.

Rakhmat, Jalaluddin. 2005. Metode Penelitian Komunikasi Dilengkapi Contoh Analisis Statistik, Bandung: PT Remaja Rosdakarya.

Rangkuti, Freddy. 2009. Strategi Promosi yang Kreatif dan Analisis Kasus Integrated Marketing Communication. Jakarta: PT. Gramedia Pustaka Utama.

Riduwan. 2004. Metode dan Teknik Menyusun Thesis. Bandung: Alfabeta.

Simamora, Bilson. 2004. Panduan Riset Perilaku Konsumen. Jakarta: Gramedia Pustaka Utama.

Siregar, Syofian. 2013. Statistik Parametrik untuk Penelitian Kuantitatif. Jakarta. PT. Bumi Aksara.

Soemanagara. 2008. Strategic Marketing Communication: Konsep Strategis dan Terapan. Bandung: Alfa Beta.

Sugiyono. 2006. Metode Pendidikan Pendekatan Kuantitatif, Kualitatif dan R\&D. Bandung: PT Rosdakarya.

Sugiyono. 2014. Metode Penelitian Kuantitatif, Kualitatif dan R\&D. Bandung: Alfabeta.

Sumarwan, Ujang. 2002. Perilaku Konsumen Teori dan Penerapannya dalam Pemasaran. Bogor: Ghalia Indonesia.

Sutaman. 2009. Pengantar Teknologi informasi. Jakarta: Bumi Aksara.

Sutabri, Tata. 2004. Analisis Sistem Informasi. Yogyakarta: Andi Yogya.

Sutisna. 2001. Perilaku Konsumen \& Komunikasi Pemasaran. Bandung: PT Remaja Rosdakarya.

Umar, Husein. 2003. Metodologi Penelitian Untuk Skripsi dan Tesis Bisnis. Jakarta: PT. Gramedia Pustaka. 
Pendit. Nyoman S. 2003. Ilmu Pariwisata Sebuah Pengantar Perdana. Jakarta : PT Percetakan Penebar Swadaya.

Wahyono, Teguh. 2006. Sistem Informasi. : Graha Ilmu.

\section{Jurnal:}

Amaly, Najla. 2014. Bauran Komunikasi Pemasaran Wisata Pasar Terapung dalam Meningkatkan Wisatawan Kota Banjarmasin. UMM. http://digilib.umm.ac.id/gdl.php?mod=browse\&op=read\&id=jiptummpp-gdlnajlaamaly-

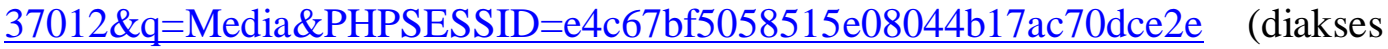
pada 25 Juni 2015 pukul 12:24).

Baloglu, Seyhmus and McCleary. 1999. A Model of Destination Image Formation. $\begin{array}{lllllr}\text { Elsevier, } & \text { vol } & 26 & \text { (4) } & \text { pp } & \text { 868-897. }\end{array}$ http://www.sciencedirect.com/science/article/pii/S0160738399000304 (diakses pada tanggal 12 Oktober 2015 pukul 22.30).

DM. Fri'as et al. 2008. Internet vs travel agencies on previsit detination image formation: An information processing view. Elsevier. http://www.sciencedirect.com/science/article/pii/S0261517707000404 (diakses pada 24 agustus 2016 pukul 12:34 wib).

Dominique FL, Sergio. 2011. Destination Image: Origins, Developments and Implications. Universidad de Santiago de Compostela, vol 9 (2), pp 305-315. http://www.pasosonline.org/Publicados/9211/PS0211_07.pdf (diakses pada tanggal 02 Desember 2015 pukul 21.00).

Echtner, CM and J.R. Brent Ritchie. 1993. The meaning and Measurement of Destination Image. The Journal of Tourism Studies Vol. 2 (2). https://www.jcu.edu.au/_data/assets/pdf_file/0006/122487/jcudev_012328.pdf (diakses pada tanggal 9 Desember 2015 pukul 19.13).

Govers, Robert et al. 2009. Promoting Tourism Destination Image. Sage. https://datapro.fiu.edu/campusedge/files/articles/kumark2519.pdf (diakses pada 21 Juni 2015 Pukul 12:30 wib).

Khairani. 2009. Analisis Variabel yang Berpengaruh Terhadap Pembentukan Citra Daerah Tujuan Wisata: Studi Kasus Wisatawan Nusantara yang Berwisatwa ke Yogyakarta Periode 2007-2009. Universitas Indonesia. lib.ui.ac.id/file?file=digital/127023-6646-Analisis\%20variabel...pdf (diakses pada 29 Juni pukul 12:30 wib).

Khodadadi, Masood. 2012. Media Discourses and Formation of Destination Image. Glasgow Caledonian University, UK. https://www.exeter.ac.uk/media/universityofexeter/centreforsportleisureandtouris m/phdcolloquium/Khodadadi.pdf (diakses pada tanggal 23 Oktober 2015 pukul 20.40). 
Luzzi L.C, Alexandre and Ana Paula M.S. 2015. Strategic Image Management: The Image of The City of Sao Paulo/SP. Academic Journals, vol 9(6), pp 288-297. http://www.academicjournals.org/journal/AJBM/article-full-textpdf/DB1AC7551981 (diakses pada 10 Agustus 2016 pukul 12.13).

Mansfeld. Yoel and Abraham Pizam. 2011. Tourism, Security and Safety. Elsevier. http://www.sciencedirect.com/science/book/9780750678988 (diakses pada 4 Juli 2016 pukul 12:20 wib).

Molina, Arturo et al. 2010. Tourism Marketing Information and Destination Image Management. African Journals of Business Management, 4(5), pp. 722728.http://academicjournals.org/article/article1380715458_Molina\%20et\%20al.pd f (diakses pada 25 Juni 2016 pukul 11.11 WIB).

Salindri, Benedecta dan Ninik Sri. 2014. Pengaruh Kualitas Informasi Webstite Terhadap Citra Pemerintah Kabupaten Wonogiri. Universitas Atma Jaya: Yogyakarta. http://e-journal.uajy.ac.id/6666/1/JURNAL.pdf (diakses pada tanggal 6 Oktober 2015 pukul 19.30).

Yulisda, Dyva dan MC Ninik SR. 2014. Pengaruh Kualitas Website Terhadap Citra (Studi Kuantitatif Kualitas Website Pemerintah Kota Yogyakarta Terhadap Citra Pemerintah Kota Yogyakarta). UAJY. http://e-journal.uajy.ac.id/6438/ (diakses pada 25 juni 2016 pukul 11:52 wib).

Zhang, Lisa. 2014. Domestic Travelers Perceived Destination Image of Shanghai. Vienna University. https://www.modul.ac.at/uploads/files/Theses/Bachelor/Lisa_Zhang_Thesis_Full .pdf (diakses pada 24 agustus 2016 pukul 12:32 wib).

\section{Internet:}

Aly. 2015. Banjarmasin Kota Pusaka Tepi Air. Kabar Banjarmasin. 26 September 2015. www.kabarbanjarmasin.com/posting/banjarmasin-kota-pusaka-tepi-air.html (diakses pada tanggal 2 Oktober 2015 pukul 11.55).

BPS Kalsel. 2016. Jumlah tamu nusantara yang menginap di hotel pada tahun 2015. Banjarmasinkota.bps.go.id..

https://banjarmasinkota.bps.go.id/linkTabelStatis/view/id/470(diakses pada 20Jjuni 2016 pukul 01:39).

Dermawan, Deni. 2001. Mengenal Teknologi Informasi. Universitas Pendidikan Indonesia.

http://file.upi.edu/Direktori/FIP/JUR. KURIKULUM DAN TEK. PENDIDIKA N/197111281998021DENI DARMAWAN/FILOSOFIS TEKNOLOGI INFORMASI DAN KOMU NIKASI.pdf (diakses pada 27 Juni pukul 12:00 wib).

Dishubkominfo Provinsi Kalsel. 2015. Dukungan Capaian Target 275.000.000 Kunjungan Wisata. Media center Kalsel. 22 September 2015. 
http://mckalsel.id/?p=8958 (diakses pada tanggal 29 September 2015 pukul 11.40).

Kementerian Pariwisata RI. 2013. Pasar Terapung Muara Kuin: Menikmati Denyut Nadi Pasar Tradisional di atas Air. Indonesia travel. http://id.indonesia.travel/sites/site/598/pasar-terapung-muara-kuin (diakses pada 20 juni 2016 pukul 02:39).

Murdy H. Herry. 2015. Banjarmasin Konsentrasi Benahi Wisata Sungai.Antara Kalsel.com.11 April 2015. www.Antarakalsel.com/berita/26063/banjarmasinkonsentrasi-benahi-wisata-sungai (diakses pada tanggal 29 September 2015 pukul 11.30).

Sadidan. 2015. Pasar Terapung Memperhatinkan. NET TV . 8 oktober 2015. http://www.youtube.com/watch?v=rlpHv57GyP8 (diakses pada tanggal 5 November 2015 pukul 12.00). 